\title{
Effects of bicarbonate/lactate-buffered neutral peritoneal dialysis fluids on angiogenesis-related proteins in patients undergoing peritoneal dialysis
}

Hiromichi Ueno ${ }^{1,2}$, Tetsu Miyamoto ${ }^{1 *}$ (1) , Hiroyuki Morimoto ${ }^{3}$, Kenya Sanada ${ }^{1}$, Ikutaro Furuno ${ }^{1}$, Kazutoshi Nakazono ${ }^{1}$, Emi Hasegawa', Akihiro Kuma', Yasushi Oginosawa', Yuki Tsuda', Masaru Araki', Masahito Tamura ${ }^{4}$, Yoichi Ueta², Yutaka Otsuji ${ }^{1}$ and Masaharu Kataoka'

\begin{abstract}
Background: In order to facilitate the safe and long-term delivery of peritoneal dialysis (PD), it is necessary to improve the biocompatibility of peritoneal dialysis fluids (PDFs). The novel bicarbonate/lactate-buffered neutral PDFs (B/L-PDFs) are expected to be improved biocompatible. This study evaluated the biocompatibility of B/L-PDFs by analysis on the profile of angiogenesis-related proteins in drained dialysate of patients undergoing PD.

Methods: Concentrations of 20 angiogenesis-related proteins in the dialysate were semi-quantitatively determined using a RayBio ${ }^{\oplus}$ Human Angiogenesis Antibody Array and were compared between B/L-PDFs and conventional lactate-buffered neutral PDFs (L-PDFs).

Results: The expression of growth-related oncogene ( $G R O a / \beta / \gamma)$, which belongs to the CXC chemokine family, decreased significantly after use of the B/L-PDFs compared to the L-PDFs $(P=0.03)$. The number of the proteins with lower level in the B/L-PDFs compared with L-PDFs was significantly negatively correlated with the PD duration (Spearman $\rho=-0.81, P=0.004$ ).

Conclusion: This study suggested that B/L-PDFs are more biocompatible than conventional PDFs.

Keywords: Bicarbonate/lactate-buffered neutral peritoneal dialysis fluid, Angiogenesis, Growth-related oncogene, Biocompatibility, Chemokine
\end{abstract}

\section{Background}

Peritoneal dialysis (PD), one of the major renal replacement therapies, has fewer cardiovascular events within several years after initiation compared to hemodialysis, and also excels in maintaining quality of life. Fluid retention and encapsulating peritoneal sclerosis (EPS) that

\footnotetext{
* Correspondence: tetsum@med.uoeh-u.ac.jp

${ }^{1}$ Second Department of Internal Medicine, University of Occupational and Environmental Health, 1-1 Iseigaoka, Yahatanishi-ku, Kitakyushu 807-8555, Japan

Full list of author information is available at the end of the article
}

occur as a result of peritoneal dysfunction prevent longterm delivery of PD [1]. Clinical and experimental evidence supports the view that continuous exposure to conventional PD fluids (PDFs) drives pathological alterations, including the loss of mesothelial cells, thickening of the submesothelial layer, and angiogenesis. Such inappropriate peritoneal remodeling ultimately leads to a high peritoneal solute transport rate, resulting in ultrafiltration failure and progressive loss of the dialyzing capacity of PD [2-5]. It is known that the deterioration of peritoneal tissue is associated with bioimcompartible

(c) The Author(s). 2021 Open Access This article is licensed under a Creative Commons Attribution 4.0 International License, which permits use, sharing, adaptation, distribution and reproduction in any medium or format, as long as you give appropriate credit to the original author(s) and the source, provide a link to the Creative Commons licence, and indicate if changes were made. The images or other third party material in this article are included in the article's Creative Commons licence, unless indicated otherwise in a credit line to the material. If material is not included in the article's Creative Commons licence and your intended use is not permitted by statutory regulation or exceeds the permitted use, you will need to obtain permission directly from the copyright holder. To view a copy of this licence, visit http://creativecommons.org/licenses/by/4.0/ The Creative Commons Public Domain Dedication waiver (http://creativecommons.org/publicdomain/zero/1.0/) applies to the data made available in this article, unless otherwise stated in a credit line to the data. 
factors such as high glucose and lactate contents, high osmolality, glucose degradation products (GDPs) and low $\mathrm{pH}$ [6]. In particular, high lactate buffer content in PDFs is a one of the important non-physiological factors that cause development of peritoneal membrane failure [7]. Despite lactate-buffered neutral PDFs (L-PDFs), which are used for majority of PD patients, having reportedly improved bioavailability, L-PDFs still include a high lactate content $(40 \mathrm{mEq} / \mathrm{L})$. Against this background, novel PDFs containing physiological concentrations $(25 \mathrm{mEq} / \mathrm{L})$ of sodium bicarbonate and low concentrations $(10 \mathrm{mEq} / \mathrm{L})$ of lactate $(\mathrm{B} / \mathrm{L}-\mathrm{PDFs})$ have recently been developed.

Low-glucose degradation product bicarbonate/lactatebuffered solutions are reported to have less cell toxicity and superior cell viability in vitro, and less neoangiogenesis and impaired ultrafiltration in rat models of PD, as compared with low $\mathrm{pH}$ lactate-buffered solutions [8-10]. Kuma et al. reported a lactate-induced reduction in cell viability, showing that apoptosis of human peritoneal mesothelial cells was markedly induced by L-PDFs, but not by B/L-PDFs, which was attenuated by knockdown of monocarboxylate transporter-1, a cell membrane lactate transporter [11].

In clinical settings, although there was no difference in peritoneal equilibration tests and adequacy (PET) between $\mathrm{B} / \mathrm{L}-\mathrm{PDFs}$ and conventional lactate-buffered low $\mathrm{pH}$ PDFs, no consistent data on ultrafiltration are available [12-15]. Few reports have shown significant reductions in effluent levels of interleukin-6(IL-6) and vascular endothelial growth factor (VEGF), and increased cancer antigen 125 (CA125) in patients using B/ L-PDFs, suggesting that B/L-PDFs may be better biocompatibility. However, these studies did not directly compare the effects of lactate as they were comparisons between $\mathrm{B} / \mathrm{L} \mathrm{PDFs}$ and conventional lactate-buffered acidic PDFs, not B/L PDFs and L-PDFs $[16,17]$.

As the most consistent change observed in the peritoneal tissue of PD-patients is submesothelial thickness coexisting with angiogenesis [18], it is relevant to study effluent levels of angiogenesis-related proteins to better understand the bioavailability of PDFs in clinical settings. We designed the present cross-over study to investigate the profile of angiogenesis-related proteins in drained dialysate of PD-patients.

\section{Methods}

\section{Study design}

We undertook an 8-week crossover trial of outpatients with maintenance PD (Fig. 1). The study was performed in accordance with the Declaration of Helsinki and was approved by the Ethics Committee of the University Hospital of University of Occupational and Environmental Health School of Medicine, Japan (H26-245). Written

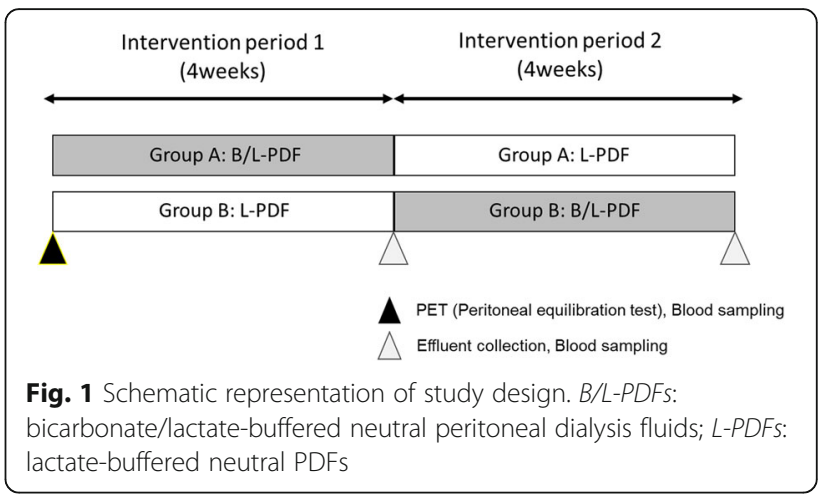

informed consent was obtained from all participants. After enrollment, patients were randomly allocated to sequential treatment with L-PDFs (Dianeal N PD-4; Baxter Healthcare, Tokyo, Japan) following B/L-PDFs (Reguneal LCa; Baxter Healthcare) (group A, $n=5$ ) or vice versa (group $B, n=5$ ). The duration of each intervention was 4 weeks with a total study period of 8 weeks. Peritoneal equilibration tests (PET) were performed at baseline. After each intervention period, 100 $\mathrm{ml}$ of drained effluent after overnight dwell and blood samplings were collected.

\section{Protein array analysis}

Twenty angiogenesis-related proteins in drained effluents were semi-quantitively determined using the RayBio C-Series Human Angiogenesis Antibody Array according to manufacturer's instructions (RayBiotech, Norcross, GA). The kit has been used in numerous studies and its reliability is guaranteed [19-21]. Briefly,
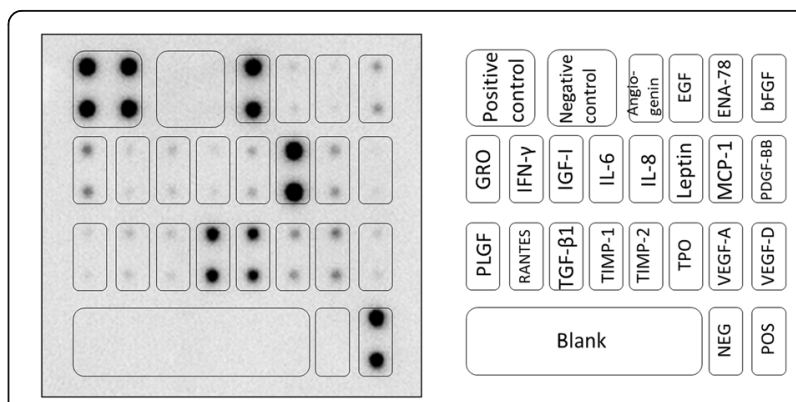

Fig. 2 Representative image obtained from protein array procedure. POS: positive control; NEG: negative control; GRO: growth related oncogene; IFN- $\gamma$ : interferon- $\gamma$; PLGF: placental growth factor; RANTES: regulated on activation, normal T cell expressed and secreted; IGF-1: insulin-like growth factor-1; TGF beta 1: transforming growth factor beta 1; IL-6: interleukin-6; TIMP-1: Tissue Inhibitor of

Metalloproteinase-1; IL-8: interleukin-8; TIMP-2: tissue inhibitor of metalloproteinase-2; EGF: epidermal growth factor; TPO: thyroid peroxidase; ENA-78: epithelial-derived neutrophil-activating protein 78; MCP-1: monocyte chemotactic protein-1; VEGF-A: vascular endothelial growth factor-A; bFGF: basic fibroblast growth factor; PDGF-BB: platelet-derived growth factor; VEGF-D: vascular endothelial growth factor-A 


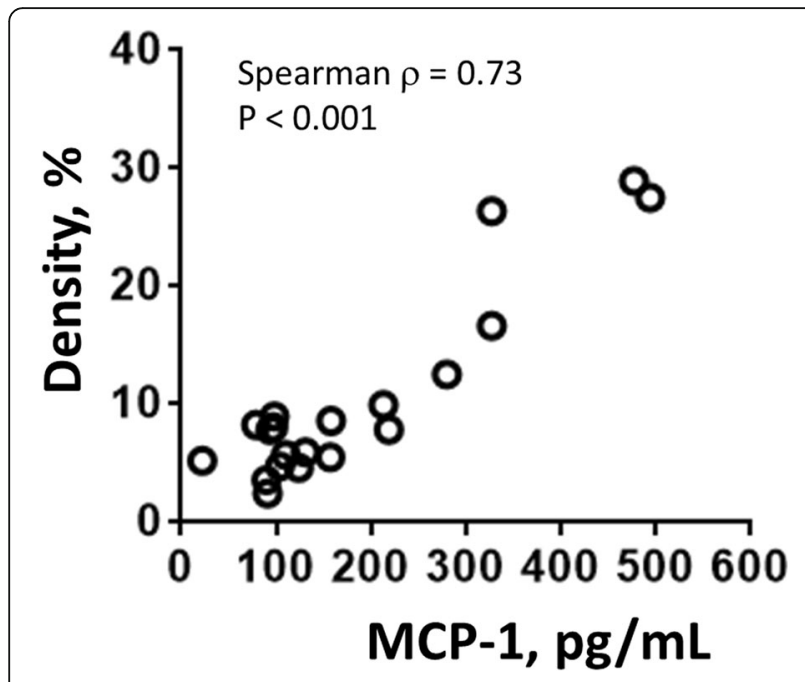

Fig. 3 Association between density of MCP-1 obtained from protein array analysis and MCP-1 levels measured by ELISA. MCP-1: monocyte chemotactic protein-1

samples were incubated with an array membrane, followed by biotinylated antibodies. Biotinylated proteins captured by the membrane-bound antibodies were detected by incubation with horseradish peroxidase (HRP)streptavidin and analysis using a chemiluminescence blot documentation system. The analyzed proteins with array map and representative image obtained from the procedure is shown in Fig. 2. Protein concentrations were expressed as the ratio (\%) of the spot density to positive control density of each protein array membrane. Intermembrane normalization was performed using the signals for positive controls on each membrane. To validate data from the C-Series Antibody Array, Monocyte Chemotactic protein-1 (MCP-1) in the drained effluents was quantified using sandwich enzyme-linked immunosorbent assay (ELISA) according to the manufacturer's instructions (Quantikine ELISA Kit, Human CCL2/MCP-1 Immunoassay; R\&D Systems, Minneapolis, MN). We compared the spot density of MCP-1 obtained from the protein array analysis with the MCP-1 levels in ELISA, and noted a significant linear correlation between the levels obtained by protein array and ELISA (Fig. 3). In addition, GRO- $\alpha$ levels in the dialysate were quantified by using ELISA according to the manufacturer's instructions (Quantikine ${ }^{\circ}$ ELISA Human CXCL1/ GRO $\alpha$ Immuno assay; R\&D system, Minneapolis, MN).

\section{Biochemical measurements}

At each time-point, blood (not fasting) was taken by venous puncture for measurement of albumin (Alb, g/ $\mathrm{dL}$ ), blood urine nitrogen (BUN, $\mathrm{mg} / \mathrm{dL}$ ), creatinine (Cre, $\mathrm{mg} / \mathrm{dL}$ ), calcium $(\mathrm{Ca}, \mathrm{mg} / \mathrm{dL})$, phosphate $(\mathrm{P}, \mathrm{mg} /$ $\mathrm{dL})$, and hemoglobin $(\mathrm{Hb}, \mathrm{g} / \mathrm{dL})$, using standard laboratory techniques.

\section{Statistics}

Spearman rank correlation analysis was used to determine the association between MCP-1 levels analyzed by protein array and by ELISA. Wilcoxon signed-rank test were used to assess treatment differences for angiogenesis-related proteins in effluents. Differences were considered statistically significant at $P<0.05$. All statistical tests were performed using JMP version 12 (SAS Institute Inc., NC).

\section{Results}

\section{Study population}

Baseline characteristics of the 10 participants are summarized in Table 1 . One of the 10 patients was female and 4 patients had diabetes mellitus. One patient was in the low PET category and 9 were in the high PET

Table 1 Study population

\begin{tabular}{|c|c|c|c|c|c|c|c|c|c|c|c|}
\hline No. & Sex & Age & $\begin{array}{l}\text { Primary } \\
\text { disease }\end{array}$ & $\begin{array}{l}\text { PD duration } \\
\text { (months) }\end{array}$ & $\begin{array}{l}\text { Albumin } \\
\text { (g/dL) }\end{array}$ & $\begin{array}{l}\text { BUN } \\
(\mathrm{mg} / \mathrm{dL})\end{array}$ & $\begin{array}{l}\text { Creatinine } \\
(\mathrm{mg} / \mathrm{dL})\end{array}$ & $\begin{array}{l}\text { Calcium } \\
\text { (mg/dL) }\end{array}$ & $\begin{array}{l}\text { Phosphate } \\
\text { (mg/dL) }\end{array}$ & $\begin{array}{l}\text { Hemoglobin } \\
(g / d L)\end{array}$ & $\begin{array}{l}\text { PET } \\
\text { category }\end{array}$ \\
\hline 1 & Male & 78 & HTN & 26 & 3.1 & 73 & 10.54 & 8.3 & 6.8 & 10.3 & $\mathrm{HA}$ \\
\hline 2 & Female & 52 & PCKD & 1 & 3.8 & 71 & 8.35 & 9.1 & 5.2 & 10.3 & Low \\
\hline 3 & Male & 66 & DN & 39 & 2.6 & 68 & 7.95 & 7.6 & 5.6 & 10.3 & $\mathrm{HA}$ \\
\hline 4 & Male & 76 & CGN & 108 & 3 & 58 & 9.9 & 8.4 & 6.2 & 13.1 & $\mathrm{HA}$ \\
\hline 5 & Male & 53 & DN & 42 & 3.7 & 43 & 8.6 & 8.6 & 4.3 & 11.6 & $\mathrm{HA}$ \\
\hline 6 & Male & 46 & HTN & 50 & 3.6 & 47 & 9.67 & 8.5 & 5.6 & 12.1 & $\mathrm{HA}$ \\
\hline 7 & Male & 64 & DN & 44 & 3.2 & 64 & 6.02 & 8.5 & 5.5 & 10.1 & $\mathrm{HA}$ \\
\hline 8 & Male & 69 & PCKD & 20 & 3.2 & 40 & 7.93 & 8.1 & 3.8 & 12 & $\mathrm{HA}$ \\
\hline 9 & Male & 70 & DN & 7 & 3.2 & 52 & 2.91 & 8.6 & 3.2 & 11.8 & $\mathrm{HA}$ \\
\hline 10 & Male & 65 & CGN & 65 & 3.6 & 73.5 & 11 & 9.5 & 5.7 & 10.2 & $\mathrm{HA}$ \\
\hline
\end{tabular}




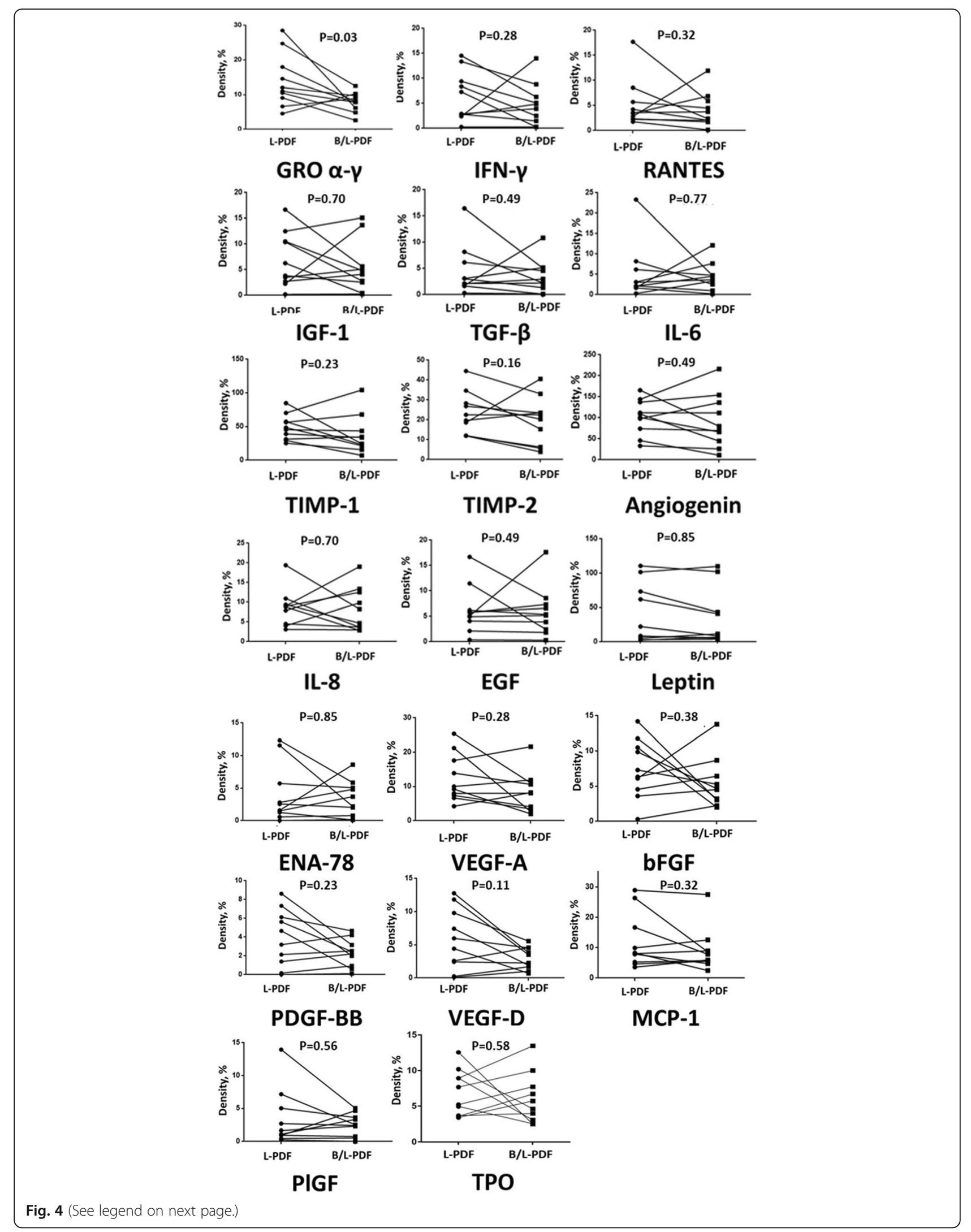


(See figure on previous page.)

Fig. 4 Change in density of 20 angiogenesis-related proteins. GRO: growth related oncogene; IFN- $\gamma$ : interferon- $\gamma$; PLGF: placental growth factor; RANTES: regulated on activation, normal T cell expressed and secreted; IGF-1: insulin-like growth factor-1; TGF beta 1: transforming growth factor beta 1; IL-6: interleukin-6; TIMP-1: tissue inhibitor of metalloproteinase-1; IL-8: interleukin-8; TIMP-2: tissue inhibitor of metalloproteinase-2; EGF: epidermal growth factor; TPO: thyroid peroxidase; ENA-78: epithelial-derived neutrophil-activating protein 78; MCP-1: monocyte chemotactic protein-1; VEGF-A: vascular endothelial growth factor-A; bFGF: basic fibroblast growth factor; PDGF-BB: platelet-derived growth factor; VEGF-D: vascular endothelial growth factor-A

category. During the study, there were no significant differences in body weight, blood pressure, serum albumin, blood urine nitrogen (BUN), creatinine, calcium, phosphate levels, and blood hemoglobin counts when either $\mathrm{B} / \mathrm{L}-\mathrm{PDFs}$ or L-PDFs were given.

\section{Angiogenesis-related protein levels in drained effluents} Among the 20 evaluated angiogenesis-related proteins (Fig. 4), effluent levels of growth-regulated oncogene $\alpha /$ $\beta / \gamma($ GRO $\alpha / \beta / \gamma$ or CXCL1/2/3) decreased significantly after use of B/L-PDFs when compared with L-PDFs $(P=$ 0.03). Levels of vascular endothelial growth factor-D (VEGF-D, $P=0.11$ ) tended to be lower in B/L-PDFs than in L-PDFs. There were no angiogenesis-related proteins studied that showed significantly higher effluent levels with B/L-PDFs.

\section{GRO-a levels in drained effluents}

The level of GRO- $\alpha$ in B/L-PDFs were significantly lower than L-PDFs (Fig. 5).

\section{Effects of dialysis duration on effluent angiogenesis- related protein levels}

Dialysis vintage had a significantly negative correlation with the number of angiogenesis-related proteins that showed lower levels when using $\mathrm{B} / \mathrm{L}-\mathrm{PDFs}$ when compared with $\mathrm{L}-$ PDFs (Spearman $\rho=-0.81, P=0.004$, Fig. 6).

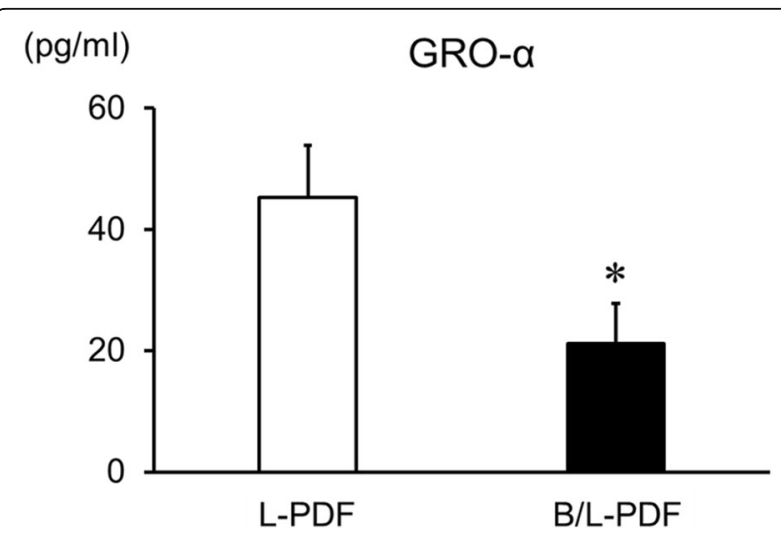

Fig. 5 The GRO-a levels measured by ELISA. Data are presented as means \pm SEM (each group at each time point, $n=6$ ). Statistically significant if $P<0.05$ using ANOVA. ${ }^{*} P<0.05,{ }^{* *} P<0.01$ compared with the L-PDFs

\section{Discussion}

Neoangiogenesis in thickened peritoneal membrane is the major morphologic change induced by long-term exposure to PDFs, resulting in an expanded vascular network leading to reduced ultrafiltration capacity $[2,18$, 22]. The present study directly evaluated the effects of lactate concentration by comparison between B/L-PDFs and L-PDFs, and showed that effluent levels of some angiogenesis-related proteins tended to be smaller in $\mathrm{B} /$ L-PDFs, especially in patients with shorter duration of PD. The kit has been used in numerous studies and its reliability is guaranteed. We demonstrated the accuracy and semi-quantitability of the kit by showing a significant linear correlation between MCP-1 levels measured by ELISA and MCP-1 levels measured by protein array.

Several studies have shown that lactate stimulates angiogenesis in the context of the adaptive response contributing to cell preservation under hypoxic conditions $[23,24]$. Although the molecular mechanisms remain elusive, bicarbonate-buffered neutral PDFs with low GDP content promotes less endothelial cell tube formation when compared to lactate-buffered neutral PDFs [25]. In rats, intraperitoneal exposure to lactate buffer, as compared with $\mathrm{pH}$-adjusted bicarbonate buffer,

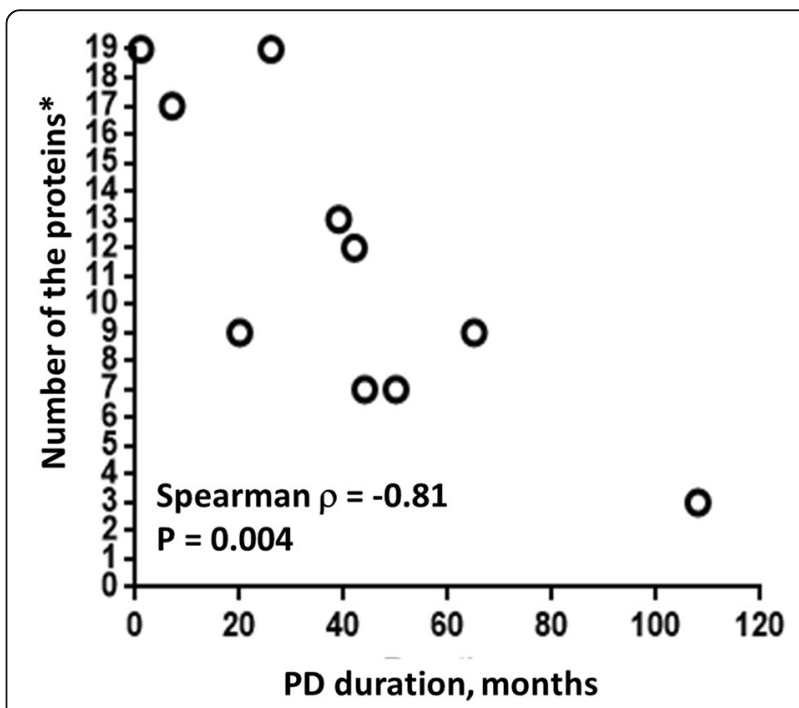

Fig. 6 Association between number of proteins that decrease in density after B/L PDFs period and PD duration. *Number of analyzed proteins that decrease in density after B/L-PDFs treatment when compared to L-PDFs treatment 
stimulates angiogenesis in the presence or absence of glucose [26]. These data support the results of the present study suggesting that high-dose lactate in PDFs may accelerate production of angiogenesis-related proteins in peritoneal membrane of PD patients.

Chemokines have a critical role in angiogenesis or vascular remodeling [27]. GRO, a member of the CXC chemokine family with an internal glutamate-leucinearginine (ELR) motif, has chemotactic and proangiogenic activities under inflammatory conditions [28]. Chemokines with an ELR motif, such as GRO and interleukin-8 (IL-8, CXCL-8), promote angiogenesis [29]. Interestingly, in this study, although no difference in effluent IL-8 levels was observed between B/L-PDFs and L-PDFs, GRO levels in the B/L PDFs group were clearly lower than with L-PDFs.

GRO has three highly homologous subtypes $(\alpha / \beta / \gamma)$. These three subtypes bind to the same receptor; however, they have different affinities and stimulate various physiological responses. In particular, GRO- $\alpha$ which is the chemokine (C-X-C motif) ligand 1 (CXCL1) has a three-dimensional structure similar to IL-8, and it has been reported that it has almost the same level of leukocyte migration ability compared with IL-8 [30, 31]. The level of GRO- $\alpha$ in B/L-PDFs was significantly lower than L-PDFs. This result supported that B/L-PDFs has improved biocompatibility compared to L-PDFs. VEGFs are key players in peritoneal neovascularization and lymphangiogenesis [22]. In this study, while density levels in effluents were higher in VEGF-D was more susceptible with L-PDFs. Terabayashi et al. recently reported that dialysate VEGF-D concentration was positively correlated with the dialysate to plasma ratio of creatinine (D/P Cr) and VEGF-D mRNA was significantly higher in the peritoneal membranes of patients with ultrafiltration failure [32]. VEGF-D may also be involved in the pathogenic process of lactate-induced peritoneal angiogenesis. To our knowledge, this is the first report showing a putative correlation between L-PDFs and GRO expression in peritoneal dialysate effluent of $\mathrm{PD}$ patients. To our knowledge, this is the first report to support that $\mathrm{B} / \mathrm{L}$ PDFs are more biocompatible PFDs than L-PDFs by examining the change of various angiogenesis-related proteins.

The number of angiogenesis-related proteins that decreased in the B/L PDFs group was significantly and negatively related to PD duration. Similar considerations were made for patient age, dialysis efficiency, and inflammatory markers. However, there was no correlation in any of the factors (data not shown). Notably, in two participants with less than 12 months of PD the densities of all proteins examined in this study were lower in the $\mathrm{B} / \mathrm{L}$ PDFs group than with L-PDFs. Interestingly, despite the maintenance of peritoneal function by PET analysis, there may be differences in the benefits of using $\mathrm{B} / \mathrm{L}$ PDFs by PD duration. Increasing peritoneal solute transport rate (PSTR) with duration of PD is often observed, which could be explained by an increase in the anatomic peritoneal membrane or an increase in the density of capillaries due to neoangiogenesis [33, 34].

Previous study reported that angiogenesis was suppressed in patients using lactate-buffered PDFs compared to patients using B/L-PDFs. However, many previous reports have compared L-acidic PDFs and B/Lneutral PDFs $[16,35,36]$. In the case of such a study design, $\mathrm{pH}$ differences could affect the results. The present study excluded the effect of $\mathrm{pH}$ and could demonstrate the high biocompatibility of B/L-PDFs.

Several limitations of the present study should be noted. First, due to the crossover design, the possibility of carry-over effects could not be removed, despite the fact that variation among participants was adequately prevented. Second, we did not examine the relationship between histological findings of the peritoneal membrane and effluent levels of the angiogenesis-related protein. Third, this study did not mechanically examine the involvement of GRO in the lactate-induced peritoneal angiogenesis.

\section{Conclusions}

The present study implies the possibility that B/L-PDFs suppress the lactate-induced production of proangiogenic proteins including CXC chemokines in peritoneal tissue, especially for the PD-patients on shorter duration of $\mathrm{PD}$, suggesting that novel $\mathrm{B} / \mathrm{L}$-PDFs are more biocompatible than conventional L-PDFs. Further mechanical studies are warranted to elucidate the putative relation between lactate buffer and angiogenesis in peritoneal membrane in PD patients.

\section{Abbreviations \\ B/L-PDFs: Bicarbonate/lactate-buffered neutral PDFs; BUN: Blood urine nitrogen; CA 125: Cancer antigen 125; D/P Cr: Dialysate to plasma ratio of creatinine; ELISA: Enzyme-linked immunosorbent assay; ELR: Internal glutamate-leucine-arginine; GRO a/ $\beta / \gamma$ : Growth-related oncogene; GDPs: Glucose degradation products; IL-6: Interleukin-6; IL-8: Interleukin-8; L- PDFs: Lactate-buffered neutral PDFs; MCP-1: Monocyte chemotactic protein- 1; PD: Peritoneal dialysis; PDFs: Peritoneal dialysis fluids; PDGF-BB: Platelet- derived growth factor-BB; $P E T$ : Peritoneal equilibration tests and adequacy; PSTR: Peritoneal solute transport rate; VEGF-D: Vascular endothelial growth factor-D}

\section{Acknowledgements}

The authors express their appreciation to Ms. Chizuko Oba and Ms. Hatsumi Nakamura for their assistance. This work was supported by a Grant-in-Aid for Scientific Research C (No. 18K11010) from the Japan Society for the Promotion of Science (JSPS).

\section{Authors' contributions}

Design of the work; H.U., T.M., Y.O. The analysis; H.U., H.M., K.S., I.F., K.N., E.M., M.K. Interpretation of data; Y.O., Y.T., M.A., M.T., Y.U., Y.O. Drafted or revised the work; T.M., M.K. All authors read and approved the final version of the manuscript and agreed to be accountable for all aspects of the work in ensuring that questions related to the accuracy are answered. 


\section{Availability of data and materials}

The datasets used and analyzed during the current study are available from the corresponding author on reasonable request.

\section{Declarations}

\section{Ethics approval and consent to participate}

The study was performed in accordance with the Declaration of Helsinki and was approved by the Ethics Committee of the University Hospital of University of Occupational and Environmental Health School of Medicine, Japan (H26-245). Written informed consent was obtained from all participants.

\section{Consent for publication}

Our report does not contain any individual person's data in any form (including any individual details, images or videos).

\section{Competing interests}

Masahito Tamura has received grants from Baxter Ltd. Hiromichi Ueno has received speech fee from Baxter Ltd. The other authors have declared that no conflict of interest exists.

\section{Author details}

'Second Department of Internal Medicine, University of Occupational and Environmental Health, 1-1 Iseigaoka, Yahatanishi-ku, Kitakyushu 807-8555, Japan. ${ }^{2}$ Depatment of Physiology, University of Occupational and Environmental Health, 1-1 Iseigaoka, Yahatanishi-ku, Kitakyushu 807-8555, Japan. ${ }^{3}$ Depatment of Anatomy, School of Medicine, University of Occupational and Environmental Health, 1-1 Iseigaoka, Yahatanishi-ku, Kitakyushu 807-8555, Japan. ${ }^{4}$ Tamura Clinic Internal Medicine, Kitakyushu 808-0131, Japan.

\section{Received: 27 December 2020 Accepted: 11 May 2021} Published online: 05 June 2021

\section{References}

1. Mizuno $M$, Ito $Y$, Tanaka A, Suzuki $Y$, Hiramatsu $H$, Watanabe $M$, et al. Peritonitis is still an important factor for withdrawal from peritoneal dialysis therapy in the Tokai area of Japan. Clin. Exp. Nephrol. 2011;15(5):727-37. https://doi.org/10.1007/s10157-011-0471-8.

2. Williams JD, Craig KJ, Topley N, von Ruhland C, Fallon M, Newman GR, et al. Morphologic changes in the peritoneal membrane of patients with renal disease. J. Am. Soc. Nephrol. 2002;13(2):470-9. https://doi.org/10.1681/ASN. V132470.

3. Williams JD, Craig KJ, von Ruhland C, et al. The natural course of peritoneal membrane biology during peritoneal dialysis. Kidney Int. Suppl. 2003;64:S439. https://doi.org/10.1046/j.1523-1755.2003.08805.x.

4. Davies SJ. Peritoneal solute transport and inflammation. Am. J. Kidney Dis. 2014;64(6):978-86. https://doi.org/10.1053/j.ajkd.2014.06.030.

5. Lambie M, Chess J, Donovan KL, Kim YL, Do JY, Lee HB, et al. Independent effects of systemic and peritoneal inflammation on peritoneal dialysis survival. J. Am. Soc. Nephrol. 2013;24(12):2071-80. https://doi.org/10.1681/A SN.2013030314.

6. García-López E, Lindholm B, Davies S. An update on peritoneal dialysis solutions. Nat. Rev. Nephrol. 2012;8(4):224-33. https://doi.org/10.1038/ nrneph.2012.13.

7. Krediet RT, Zweers MM, van Westrhenen R, et al. Effects of reducing the lactate and glucose content of PD solutions on the peritoneum. Is the future GLAD? NDT Plus. 2008;1:iv56-62.

8. Mortier S, Faict D, Lameire NH, de Vriese A. Benefits of switching from a conventional to a low-GDP bicarbonate/lactate-buffered dialysis solution in a rat model. Kidney Int. 2005;67(4):1559-65. https://doi.org/10.1111/j.1523-1 755.2005.00237.x.

9. Ogata S, Naito T, Yorioka N, et al. Effect of lactate and bicarbonate on human peritoneal mesothelial cells, fibroblasts and vascular endothelial cells, and the role of basic fibroblast growth factor. Nephrol. Dial. Transplant. 2004;19(11):2831-7. https://doi.org/10.1093/ndt/gfh478.

10. Plum J, Razeghi P, Lordnejad RM, Perniok A, Fleisch M, Fußhöller A, et al. Peritoneal dialysis fluids with a physiologic $\mathrm{pH}$ based on either lactate or bicarbonate buffer-effects on human mesothelial cells. Am J Kidney Dis. 2001;38(4):867-75. https://doi.org/10.1053/ajkd.2001.27709.
11. Kuma A, Tamura M, Ishimatsu N, Harada Y, Izumi H, Miyamoto T, et al. Monocarboxylate transporter-1 mediates the protective effects of neutral$\mathrm{pH}$ bicarbonate/lactate-buffered peritoneal dialysis fluid on cell viability and apoptosis. Ther. Apher. Dial. 2017;21(1):62-70. https://doi.org/10.1111/17449987.12476.

12. Otte K, Gonzalez MT, Bajo M-A, del Peso G, Heaf J, Erauzkin GG, et al. Clinical experience with a new bicarbonate $(25 \mathrm{mmol} / \mathrm{L}) /$ lactate $(10 \mathrm{mmol} / \mathrm{L})$ peritoneal dialysis solution. Perit. Dial. Int. 2003;23(2):138-45. https://doi. org/10.1177/089686080302300208.

13. Tranaeus A. A long-term study of a bicarbonate/lactate-based peritoneal dialysis solution--clinical benefits. The Bicarbonate/Lactate Study Group. Perit. Dial. Int. 2000;20(5):516-23.

14. Fang W, Mullan R, Shah H, Mujais S, Bargman JM, Oreopoulos DG. Comparison between bicarbonate/lactate and standard lactate dialysis solution in peritoneal transport and ultrafiltration: a prospective, crossover single-dwell study. Perit. Dial. Int. 2008;28(1):35-43. https://doi.org/10.1177/ 089686080802800108

15. Schmitt CP, Nau B, Gemulla G, Bonzel KE, Hölttä T, Testa S, et al. Effect of the dialysis fluid buffer on peritoneal membrane function in children. Clin. J. Am. Soc. Nephrol. 2013;8(1):108-15. https://doi.org/10.2215/CJN.00690112.

16. Pajek J, Kveder R, Bren A, Guček A, Ihan A, Osredkar J, et al. Short-term effects of a new bicarbonate/lactate-buffered and conventional peritoneal dialysis fluid on peritoneal and systemic inflammation in CAPD patients: a randomized controlled study. Perit. Dial. Int. 2008;28(1):44-52. https://doi. org/10.1177/089686080802800109.

17. Cooker LA, Luneburg P, Holmes CJ, et al. Interleukin-6 levels decrease in effluent from patients dialyzed with bicarbonate/lactate-based peritoneal dialysis solutions. Perit. Dial. Int. 2001;21(Suppl 3):S102-7.

18. Devuyst O, Margetts PJ, Topley N. The pathophysiology of the peritoneal membrane. J. Am. Soc. Nephrol. 2010;21(7):1077-85. https://doi.org/10.1 681/ASN.2009070694.

19. Wang D, Wang H, Brown J, Daikoku T, Ning W, Shi Q, et al. CXCL1 induced by prostaglandin E2 promotes angiogenesis in colorectal cancer. J. Exp. Med. 2006;203(4):941-51. https://doi.org/10.1084/jem.20052124.

20. McLachlan E, Shao Q, Wang H, Langlois S, Laird DW. Connexins act as tumor suppressors in three-dimensional mammary cell organoids by regulating differentiation and angiogenesis. Cancer Res. 2006;66(20):9886-94. https://doi.org/10.1158/0008-5472.CAN-05-4302.

21. Rezzola S, Corsini M, Chiodelli P, Cancarini A, Nawaz IM, Coltrini D, et al. Inflammation and $\mathrm{N}$-formyl peptide receptors mediate the angiogenic activity of human vitreous humour in proliferative diabetic retinopathy. Diabetologia. 2017;60(4):719-28. https://doi.org/10.1007/s00125-016-4204-0.

22. Stavenuiter AWD, Schilte MN, Ter Wee PM, et al. Angiogenesis in peritoneal dialysis. Kidney Blood Press. Res. 2011;34(4):245-52. https://doi.org/10.1159/ 000326953.

23. Porporato PE, Payen VL, De Saedeleer CJ, et al. Lactate stimulates angiogenesis and accelerates the healing of superficial and ischemic wounds in mice. Angiogenesis. 2012;15(4):581-92. https://doi.org/10.1007/s1 0456-012-9282-0.

24. Kumar VBS, Viji RI, Kiran MS, Sudhakaran PR. Endothelial cell response to lactate: implication of PAR modification of VEGF. J. Cell. Physiol. 2007;211(2): 477-85. https://doi.org/10.1002/jcp.20955.

25. Eich G, Bartosova M, Tischer C, Wlodkowski T, Schaefer B, Pichl S, et al. Bicarbonate buffered peritoneal dialysis fluid upregulates angiopoietin-1 and promotes vessel maturation. PLoS One. 2017;12(12):e0189903. https:// doi.org/10.1371/journal.pone.0189903.

26. Albrektsson A, Bazargani F, Wieslander A, Braide M. Peritoneal dialysis fluidinduced angiogenesis in rat mesentery is increased by lactate in the presence or absence of glucose. ASAIO J. 2006;52(3):276-81. https://doi. org/10.1097/01.mat.0000219065.26807.27.

27. Schober A. Chemokines in vascular dysfunction and remodeling. Arterioscler. Thromb. Vasc. Biol. 2008;28(11):1950-9. https:/doi.org/10.1161/ATVBAHA.107.161224.

28. Bechara C, Wang X, Chai H, Lin PH, Yao Q, Chen C. Growth-related oncogene-alpha induces endothelial dysfunction through oxidative stress and downregulation of eNOS in porcine coronary arteries. Am. J. Physiol. Heart Circ. Physiol. 2007;293(5):H3088-95. https://doi.org/10.1152/ajpheart. 00473.2007

29. Strieter RM, Polverini PJ, Kunkel SL, Arenberg DA, Burdick MD, Kasper J, et al. The functional role of the ELR motif in CXC chemokine-mediated angiogenesis. J. Biol. Chem. 1995;270(45):27348-57. https://doi.org/10.1074/ jbc.270.45.27348. 
30. Moser B, Clark-Lewis I, Zwahlen R, Baggiolini M. Neutrophil-activating properties of the melanoma growth-stimulatory activity. J. Exp. Med. 1990; 171(5):1797-802. https://doi.org/10.1084/jem.171.5.1797.

31. Schumacher C, Clark-Lewis I, Baggiolini M, Moser B. High- and low-affinity binding of GRO alpha and neutrophil-activating peptide 2 to interleukin 8 receptors on human neutrophils. Proc. Natl. Acad. Sci. U. S. A. 1992;89(21): 10542-6. https://doi.org/10.1073/pnas.89.21.10542.

32. Terabayashi T, Ito Y, Mizuno M, Suzuki Y, Kinashi H, Sakata F, et al. Vascular endothelial growth factor receptor-3 is a novel target to improve net ultrafiltration in methylglyoxal-induced peritoneal injury. Lab. Invest. 2015; 95(9):1029-43. https://doi.org/10.1038/labinvest.2015.87.

33. Davies SJ. Longitudinal relationship between solute transport and ultrafiltration capacity in peritoneal dialysis patients. Kidney Int. 2004;66(6): 2437-45. https://doi.org/10.1111/j.1523-1755.2004.66021.x.

34. Yu Z, Lambie M, Davies SJ. Longitudinal study of small solute transport and peritoneal protein clearance in peritoneal dialysis patients. Clin. J. Am. Soc. Nephrol. 2014;9(2):326-34. https://doi.org/10.2215/CJN.04420413.

35. Fusshoeller A, Plail M, Grabensee B, Plum J. Biocompatibility pattern of a bicarbonate/lactate-buffered peritoneal dialysis fluid in APD: a prospective, randomized study. Nephrol. Dial. Transplant. 2004;19(8):2101-6. https://doi. org/10.1093/ndt/gfh326.

36. Perl J, Nessim SJ, Bargman JM. The biocompatibility of neutral pH, low-GDP peritoneal dialysis solutions: benefit at bench, bedside, or both? Kidney Int. 2011;79(8):814-24. https://doi.org/10.1038/ki.2010.515.

\section{Publisher's Note}

Springer Nature remains neutral with regard to jurisdictional claims in published maps and institutional affiliations.

Ready to submit your research? Choose BMC and benefit from:

- fast, convenient online submission

- thorough peer review by experienced researchers in your field

- rapid publication on acceptance

- support for research data, including large and complex data types

- gold Open Access which fosters wider collaboration and increased citations

- maximum visibility for your research: over $100 \mathrm{M}$ website views per year

At $\mathrm{BMC}$, research is always in progress.

Learn more biomedcentral.com/submissions 